\title{
MASSIF ANORTHOSITES: ANOTHER PARTISAN REVIEW
}

\author{
Jean-Clair DUCHESNE \\ L.A. Géologie, Pétrologie, Géochimie, Université de Liège, B-4000 Sart-Tilman, Belgium
}

\begin{abstract}
This review mainly concerns Proterozoic deformed massif anorthosites occurring in the Grenville Province and its South Norwegian extension (Rogaland). Evidence of syn-emplacement deformation during Grenvillian times contradicts the hypothesis of tectonic reworking. Long cooling histories at depth, or rejuvenation by partial melting of older solid masses can explain that ages older than Grenvillian are measured in the anorthosite. No unique magma is parental to the anorthosite suite. Acidic rocks can result from anatexis or from fractionation of jotunitic liquids. Most jotunites are not comagmatic with massif anorthosites, but are produced by partial melting of crustal rocks basic to intermediate compositions. Massif anorthosites contain giant Al-opx (7-9\% $\mathrm{Al}_{2} \mathrm{O}_{3}$, plagioclase exsolutions) produced by cotectic crystallization from basic liquids at depth. They are carried to the level of emplacement either by an hyper-feldspathic liquid, which intrudes shallower magma chambers in atectonic conditions; or, by a plagioclase crystal mush, which rises diapirically and deforms its envelope and its own mass.
\end{abstract}

\section{FOREWORD}

A few characteristics of the scientific community concerned with anorthosites are here put forward for the benefit of those not familiar with the subject.

There is a relatively small number of geologists involved. Their publications, though not numerous, are usually important contributions (books or memoirs) covering the field data, geological maps, petrology, geochemistry, etc. about the particular massif they have been studying for many years. These contributions are milestones in the development of our knowledge of anorthosites and moreover have a bearing on many topics in igneous and metamorphic petrology, structural geology and geodynamics. They provide models of high internal consistency which make the most of the data collected. These models are however very vulnerable to new approaches and techniques such as trace element geochemistry or $\mathrm{Sm} / \mathrm{Nd}$ isotope geochemistry and it takes a long time for these new constraints to be taken into account and to modify the old model.

In the intervals of these major publications the scientific community has to fall back on short abstracts presented at Geological Society meetings, unpublished theses and internal reports of restricted diffusion, which only indicate the matters into consideration rather than providing evidence $\left(^{1}\right)$. Only readers capable of reading between the lines are able to forecast the next model.

This situation has not been simplified by the recent appearance of an otherwise excellent review paper (Morse, 1982) which admits of being partisan. This means that a consensus is far from being reached inside the anorthosite community. Since Morse's paper is mainly based on the experience he gained in the study of Labrador anorthosites, the present author for a change will look at the anorthosite problem mainly from a South Norwegian point of view.

\section{VARIOUS TYPES OF ANORTHOSITES}

The present paper is mainly concerned with massif-type anorthosites, igneous bodies of huge dimensions (several tens of $\mathrm{km}$ in diameter) and of monotonous petrographic character in which a plagioclase of restricted chemical composition accounts for more than $90 \%$ of the mineral content of the rock. They are associated in time and space with approximately equal volumes of acidic rocks together with minor amounts of rocks richer in mafics -norites, troctolites, jotunites (ferrodiorites), Fe-Ti ores. These rocks altogether constitute the so-called anorthositic suite. These massifs are essentially Proterozoic in age.

Archean anorthosites -such as Fiskeneasset, W.Greenland; Messina, Limpopo belt, S. Africa; Sittampundi, S.India; Ness and Rodel, Outer Hebrides, U.K.(see the review of Windley et al., 1981); Vaskojoki, N.Finland (Moreau, 1981)- belong to a different category. They form layered bodies, strongly recrystallized and 
metamorphosed in various facies conditions possibly with some metasomatic transformation. The Fiskeneasset anorthosite is associated with ultramafics, chromitites, gabbros and leucogabbros and presents chemical consanguinity with the adjacent amphibolites. The parental magma is difficult to assess with accuracy due to the cumulate nature of the rocks and the possible subsequent chemical alteration. An overall basaltic nature is however inferred from trace element studies (Weaver et al., 1982).

Lunar anorthosites are also different from massif anorthosites. They are believed to form a major component of the lunar highlands. A cumulative process in the early stages of the formation of the Moon's crust by flotation of plagioclase in a basaltic magma has been commonly advocated for their genesis (Taylor, 1975; Smith, 1982). Trace elements in the plagioclase are however so dispersed that a unique parental magma is highly unlikely. More complex models have to be considered.

Anorthosites occurring in the ring complexes of Niger and associated with alkaline granites, first mentioned by Black (1965), are nowadays commonly discussed within the anorthosite problem (Moreau, 1982), since Emslie (1973) put forward the chemical similarities between the alkaline granites and the acidic products associated with massif anorthosites. The straightforward tectonic setting -"aborted rift" - of the Niger granites has also provided an appealing explanation for those who favour an emplacement of massif anorthosite in anorogenic environment. The strong bimodal distribution of the rock types opposing basic to acidic rocks is another point in common with massif anorthosites. The rock types occur in quite different geological settings, well displayed in the Abontorok complex (Moreau, 1982): anorthosites and associated gabbroic rocks have partly crystallized at depth and partly in a lopolithic subvolcanic magma chamber; on the other hand, the acidic rocks have intruded later in a ring dyke system. Thus the relation at depth between the two magma types cannot be directly assessed.

\section{ANORTHOSITES IN THE NORTH ATLANTIC PROVINCES}

The most extensively studied massif anorthosites are those of the North Atlantic Provinces (Adirondacks, Quebec, Labrador, Rogaland in S.Norway) where they represent a large areal proportion of the crystalline terrains (up to $20 \%$ ). In order better to understand the geodynamic evolution of these large parts of the continental crust during the Proterozoic, the anorthositic phenomenon must obviously be taken into account. There is thus a strong need for petrogenetic models to explain the origin and evolution of these rocks. The matter is of crucial interest in the Grenville Province in North America as well as in its Sveconorwegian extension in Scandinavia, which are currently considered as the best examples available of Proterozoic orogens (Windley, 1977; Dewey and Burke, 1973; Falkum and Petersen, 1980; Baer, 1981). It is obvious that the opinions of the petrologists involved in anorthositic studies have to be integrated with those from other disciplines in search of a large-scale plate tectonic or other model.

\subsection{Relation between Labrador and Grenville anorthosites}

A first point of interest is the relation between Labrador and Grenville anorthosites. Massif anorthosites extend on each side of the limit between the Grenville Province in Quebec and the Nain Province in Labrador. In Labrador the anorthosites such as Michikamau, Harp Lake and Nain were intruded in Paleohelikian times (1.51.4 Gyr - see Emslie, 1978, 1980) in anorogenic conditions and consequently are not deformed. South of the Grenville Front most anorthosites are deformed (e.g. Adirondacks, Morin, Allard Lake, Lac St-Jean, Rogaland S.Norway). The degree of deformation can vary from massif to massif and even from place to place in the same massif. Grenvillian ages (1.15-0.9 Gyr) have been measured in the metamorphic envelope close to the contact with the anorthositic mass. It has thus been commonly admitted that the deformation was due to a metamorphic reworking during the Grenville orogeny. In agreement with this hypothesis, ages as old as ca 1.6 Gyr have been obtained for anorthosites lying south of the Grenville Front (Mealy Mtns, Emslie in Morse, 1982). And the development of $\mathrm{Sm}-\mathrm{Nd}$ and $\mathrm{Pb}-\mathrm{Pb}$ geochronology, which allows measurement on the anorthosite itself, has also given ages older than the Grenvillian interval, e.g. 1.2 Gyr (Sm-Nd) for the Marcy anorthosite, Adirondacks (Ashwal et al., 1980), and $1.5 \mathrm{Gyr}(\mathrm{Pb}-\mathrm{Pb}$ ) for the Egersund-Ogna anorthosite, Rogaland (Weis and Duchesne, 1983). The deformed Grenville anorthosites, that we call Grenville anorthosites for short in this paper, would thus appear as reworked Labrador anorthosites.

\subsection{Evidence of syn-emplacement deformation.}

This view is however somewhat oversimplified. Detailed structural work in and outside some massifs does not completely fit the reworking model. Martignole and Schrijver $(1970,1972)$ have found inclusions of Grenville Supergroup metasediments in the Morin massif. Moreover they brought many indications that the deformation in the envelope of Morin could be due to the emplacement of the anorthosite (syn-emplacement deformation), not 
to a regional stress-field. They were also able to recognize within the igneous body a continuous series of intermediates between protoclastic and granoblastic textures. They thus opened the way to a quite different interpretation in which the emplacement of the anorthositic body by buoyant forces generates its own deformation not only in the surrounding gneisses but also inside the igneous body itself.

Evidence of diapirism of the Morin massif was later obtained from the petrofabric of surrounding granulites (Barraud and Martignole, 1984). The quartz c-axes tend to be oriented perpendicular to the contact, that is in the direction of major stresses which were acting during the crystallization. This pattern is consistent with the hypothesis of a diapiric ascent and spreading of the anorthositic mass. A similar gravity-induced emplacement model has also been developed by Woussen et al. (1981) for the Lac St-Jean anorthosite massif. The deformation of the envelope also results from the diapiric ascent of the anorthosite along decreasing pressure-temperature conditions.

In Rogaland Norway, detailed mapping by Maquil (1980) has led Duchesne and Maquil (1981) also to support a diapiric uprise of the Egersund-Ogna massif, generating a deformation in the surrounding gneisses and also within the inner margin of the massif, where anorthosite and leuconorite are strongly foliated. Blocky fragments of foliated anorthosite, similar in trace element composition to the inner margin, are frequently found embedded in the anorthosite. This provides evidence that marginal parts were already deformed when other parts of the massif were still capable to intrude. Two-pyroxene geothermometry (Maquil and Duchesne, 1984) also indicate that deformation in the margin took place at a higher temperature than the crystallization temperature of late stage liquids and also in excess of ca. $100{ }^{\circ} \mathrm{C}$ over that of the envelope .

These pieces of evidence (Morin, Egersund-Ogna, Lac St Jean) show that the reworking hypothesis is untenable, since it cannot explain all field relations in some massifs. On the other hand they favour a model in which the emplacement takes place over a large interval of $\mathrm{P}, \mathrm{T}$ conditions (as developed below), with continuous deformation starting in the magmatic stage and extending well into the solid stage. The interval of time necessary to achieve the continuous act of intrusion-deformation is unknown but likely to have been very long. The extreme coarseness of some anorthosite facies, where plagioclase and orthopyroxene can reach meter-size dimensions, the anhydrous refractory nature of the granulite gneisses of the envelope, the high temperature of intrusion $\left(\mathrm{ca} .1200^{\circ} \mathrm{C}\right.$ ) as well as the relatively high regional temperature also support very slow cooling rates for the igneous masses.

Ashwal et al.(1980) have measured a Sm-Nd age 300 myr older than the $\mathrm{Rb}-\mathrm{Sr}$ age in the Marcy anorthosite (Adirondacks). They interpreted the gap as being due to differences in the closing temperatures of the isotopic systems and suggested that the Sm-Nd indicates the crystallization age, and the Rb-Sr, the metamorphism. The data could as well be interpreted in terms of a long cooling history. A similar explanation can also hold for the Egersund-Ogna, where $\mathrm{Pb}-\mathrm{Pb}$ age on megacrysts (Weis and Duchesne, 1983) are older than those recorded by $\mathrm{Rb}-\mathrm{Sr}$ or zircon in the envelope near the contact. An alternative explanation is a reactivation of an older anorthosite during the Grenville-Sveconorwegian orogeny. Partial melting at depth (see below) of a small amount of the anorthosite would be sufficient to start a process of diapiric uprise and emplacement at high temperature. More geochronological data, mainly by Sm-Nd isotopes, and a better understanding of the petrogenetic significance of $\mathrm{Pb}-\mathrm{Pb}$ ages are however needed to go further.

\section{PARENTAL MAGMAS AND THE ANORTHOSITIC SUITE}

In the elaboration of plate tectonic models a major constraint is the chemical composition of the magmas and the type of magma series which develop in the process. On uniformitarian grounds it is admitted that calc-alkaline magmas imply subduction, alkali basalts in a continental environment favour rifting, low-K tholeiites point to oceanic environments, etc. Though many criteria are ambiguous and some confusion still exists in the determination of magmatic series, especially when volcanics are to be compared with plutonic rocks, it is tantalizing to apply the method to the anorthosites.

A general agreement is however far from being reached on the nature of the parental magma of the anorthosites. A large spectrum of compositions has been proposed from basaltic to granodioritic compositions (see Isachsen, 1969; De Waard et al., 1974), depending on which members of the anorthosite series are taken in the differentiation sequence.

\subsection{Acidic rocks: an anatectic origin}

It is nowadays commonly admitted that acidic rocks are not comagmatic with anorthosites (Emslie, 1978; Morse, 
1982; Ashwal and Seifert, 1980). Their close spatial and chronological relation with massif-type anorthosites simply means that they are coeval, i.e. generated by the same geological event. Strontium isotopic studies (see Emslie, 1978; Duchesne and Demaiffe, 1978) frequently show an initial ratio lower in the anorthosites than in acidic rocks and this fact is taken as evidence of different sources: a mantle origin for the anorthosite and a crustal origin for the acidic rocks, the latter implying anatexis of supracrustal rocks, triggered by the igneous phenomenon. Since it is admitted that the lower crust has a low Sr initial ratio, the acidic rocks which have a low initial ratio comparable to that of the anorthosites are also considered of anatectic origin.

The experimental work of Wendlandt (1981) give promising results in the study of anatexis in the granulite facies conditions. Under low fugacity of water or high $\mathrm{CO}_{2}$ total pressure, anatectic melts are lower in $\mathrm{SiO}_{2}$ and higher in $\mathrm{K}_{2} \mathrm{O}$ and $\mathrm{MgO}$ (charnockite analogue) than those produced in the presence of a water-rich fluid (granite analogue).

\subsection{Evidence of contamination}

Nevertheless several complications can arise which tend to show that a clear-cut distinction is hard to draw between the anorthosite series (anorthosite, leuconorite and norite) and the acidic rocks (mangerites and quartzmangerites)

In the Hidra leuconoritic body (S.Norway), the relationship between anorthosite and acidic rocks is readily observed at different scales. Cumulates of plagioclase have been described (Demaiffe et al., 1973; Demaiffe and Hertogen, 1981) in the interstices of which a granophyric association of granitic composition has crystallized. At the scale of the massif, a similar relation between anorthosite and acidic rocks is provided by occurrence of a network of acidic veins, preferentially developed in the central leuconoritic part of the massif. Trace element modeling and isotopic studies (Duchesne and Demaiffe, 1978; Demaiffe et al., 1979; Demaiffe and Hertogen, 1981; Weis and Demaiffe, 1983) indicate that derivation of the acidic rocks by fractional crystallization is a plausible mechanism but requires contamination of the late stage liquids with material from the granulite envelope. The nature of the contamination process (bulk contamination by hybridization, assimilation, isotopic reequilibration by fluid circulation) has not been specified, but, according to the present author, hybridization by back-veining seems likely.

Contamination has also been invoked in the last stage of crystallization of the Bjerkrem-Sogndal lopolith (Rogaland), where P. Michot $(1960,1965)$ has demonstrated the existence of a complete series of rocks from anorthosite to quartz-mangerite, with all transition members of leuconoritic, noritic and mangeritic composition. Bjerkrem-Sogndal was thus strong evidence in favour of the comagmatic origin of the two extreme rock types. Isotopic studies (Demaiffe et al., 1979) however showed that the acidic rocks (mangerites and quartz-mangerites) have a Sr initial ratio (0.7105) distinctly higher than in the more basic members of the series $(0.7056$ in the anorthosites, leuconorites and norites). Wielens et al. (1981) confirmed a value of 0.7075 with a better isochron restricted to quartz-mangerites. This indicates that at least some contamination with material coming from the envelope has taken place in the last stage of the crystallization of the lopolith. Trace element modeling (Duchesne, 1978; Demaiffe et al., 1979) was however unable to unravel the mechanism of contamination.

Zircon morphology and chemistry (Caruba et al., 1984) in the quartz-mangerites reveals a complex history. Zircon grains with U-rich cores are common as well as more complex ones in which an U-poor core is successively rimmed by a corroded U-rich zone and an U-poor envelope. This indeed contradicts an origin by a simple fractional crystallization process and supports either a bulk contamination or a different origin for the quartz-mangerites.

The quartz-mangeritic unit which is structurally the highest unit of the lopolith is separated from the mangeritic unit in the north and northwest by a zone rich in country rock xenoliths (Michot, 1960; Hermans et al., 1975). It is therefore tempting to consider the quartz-mangerites as a completely separated intrusion of crustal anatectic melts (Wiebe, 1984). In such a model the mangerites would in fact represent the last unit on top of the magma chamber made up by the residual liquid of the crystallization sequence. This is however in conflict with rareearth evidence (Demaiffe et al., 1979; Wiebe, 1984; Duchesne et al., 1984) which indicates that the mangerites are not liquids but cumulate rocks. They indeed show a positive europium anomaly. Thus in the two-intrusion model the question is to locate the last residual liquids. A possible answer implies a unique intrusion and the mixing of the late stage residual liquids of the lopolith with anatectic melts invading the magma chamber at the end of the crystallization. This is consistent with contamination by hybridization.

Petersen (1980a, 1980b) has remarkably demonstrated in the Kleivan granite (Lyngdal, S.Norway) a complete 
transition between charnockitic and granitic rocks. Modeling of major and trace elements shows that granitic rocks derive from charnockites by a continuous fractional crystallization process involving separation and sinking of noritic and mangeritic cumulates. Together with a low $\mathrm{Sr}$ initial ratio $(0.7053)$ this model points to a close link between the Kleivan granite and basic cumulates, which according to Petersen, can be equivalent to the neighbouring anorthosites.

\subsection{Jotunitic rocks}

Jotunites, also named monzonorites (Michot) or ferro-diorites (Emslie), also belong to the anorthosite series. Though of less importance in volume than anorthosites and acidic rocks, they are ubiquitous in all anorthosite provinces. They usually form dykes and small intrusions, spatially related to the contacts between the anorthosite massif and their envelope or between anorthosite and associated acidic rocks. Chemically they are high in total $\mathrm{Fe}, \mathrm{TiO}_{2}$ and $\mathrm{P}_{2} \mathrm{O}_{5}$; they have high $\mathrm{FeO} / \mathrm{MgO}$ ratios, $\mathrm{K}_{2} \mathrm{O}$ content around $1.2 \%$, low $\mathrm{SiO}_{2}$ and moderate to low $\mathrm{Al}_{2} \mathrm{O}_{3}$ (Emslie, 1978).

Various petrogenetic processes have been invoked for their formation.

1. Classicaly jotunites are considered as comagmatic with the anorthosites (Buddington, 1972; Ashwal, 1982; Wiebe, 1984). Continuous separation of plagioclase, alone or with a small amount of mafic minerals, from a parental magma, whatever its composition, drives the residual liquids towards high values of Fe, Ti, P, K, etc... The similarity with the Skaergaard evolution leading to ferro-diorites is striking. Several variants of this interpretation extend the relation to the whole anorthosite suite. Jotunites are considered as residual liquids intermediate between norites and acidic rocks (Michot, 1960, 1965; Philpotts, 1966; Schrijver, 1975; Wiebe, 1984).

2. Jotunites are considered as one of the parental magmas giving rise to anorthosites (Duchesne and Demaiffe, 1978). Found as a chilled margin in the Hidra body, their composition can account for the series of rocks of Hidra (Demaiffe and Hertogen, 1981). Moreover, trace element modeling of the Bjerkrem-Sogndal sequence of rocks (Duchesne, 1978; Roelandts and Duchesne, 1979) also points to a jotunite composition for the BjerkremSogndal magma. Fine-grained jotunitic rocks recently discovered at Tjörn (Tobi, pers.comm.) at the contact of the envelope and the lower part of the Bjerkrem-Sogndal cumulates have an overall geochemical character compatible with this interpretation (Duchesne et al., unpublished).

3. Jotunites are immiscible liquids conjugate with quartz-mangeritic liquids (Wiebe, 1979; Philpotts, 1981).

4. Jotunites are not comagmatic with anorthosites but represent residual liquids from the fractionation of tholeiitic basaltic magma dominated by subtraction of mafic silicates in sub-crustal magma chamber (Emslie, 1978, 1980).

From trace element evidence it is obvious that the first two processes do not exclude each other. Mafic-rich dyke rocks (also rich in Fe-Ti oxides and apatite) associated with the Adirondacks anorthosites have REE characteristics, namely a well defined Eu negative anomaly, expected for late-stage differentiates of the anorthosites (Ashwal and Seifert, 1980).

On the other hand jotunites from Rogaland, as well as from Harp Lake, Labrador (Chou and Emslie, 1979) display no significant $\mathrm{Eu}$ anomaly, which would not be the case if they were residual liquids left after the formation of anorthosite. The separation of large quantities of plagioclase with a strong positive Eu anomaly would be bound to depress the residual liquid in Eu and give rise to a negative Eu anomaly. Ashwal and Seifert (1980) have proposed another mechanism to cancel the Eu anomaly. They suggest the mixing of early cumulate crystals and late stage residual liquid in the right proportions to produce a rock without Eu anomaly. This mechanism though theoretically possible must be rejected since it cannot explain by which mechanism the right proportions of mixing are always realized.

Another approach to the problem considers the role of apatite. Jotunitic magmas in the course of fractional crystallization quickly become saturated with regard to apatite (Watson, 1979). As soon as apatite joins the other liquidus minerals it will have a drastic influence on the bulk partition coefficient between the cumulus minerals and the liquid, because of its affinity for REE (high partition coefficients and strong variation with temperature and chemical composition of the magma). Moreover apatite crystallization has an inverse effect to that of the plagioclase relative to $\mathrm{Eu}$ because its affinity for $\mathrm{Eu}$ is lower than for the other REE. Examples of such a buffering effect of apatite have been developed in Bjerkrem-Sogndal (Roelandts and Duchesne, 1979; Duchesne, 
1978) and in the Egersund dyke system (Duchesne et al., 1984).

Rejection of the residual liquid hypothesis can be better demonstrated on the basis of Sr isotopic compositions. Jotunitic rocks in Rogaland form a system of dykes extending through all massifs (Michot, 1960). Recent data (Duchesne et al., 1984) show that the dykes have $\mathrm{Sr}$ initial ratios between 0.7060 and 0.7085 , values significantly higher than those for the massif-type anorthosites (Egersund-Ogna massif: 0.7032-0.7045; HålandHelleren and Åna-Sira massifs: 0.7050-0.7063) (Duchesne and Demaiffe, 1978). The Lomland dyke is particularly typical with values around 0.708 . From this it can be inferred that jotunites and massif anorthosites are not comagmatic and come from different sources with variable $\mathrm{Sr}$ initial ratios. The mantle origin of the jotunite suggested on the basis of the low value for the Hidra body $(0.7050-0.7060)$ by Duchesne et al. (1974) is not anymore consistent. Other models must be elaborated: a two-step process with generation of a magma in the mantle and contamination in an intermediate magma chamber is likely, and so is a direct partial fusion process of a lower intermediate to basic continental crust.

\subsection{Relations between jotunites and acidic rocks}

Another interesting point is the relationship of jotunites with acidic rocks. Within the same dyke it is frequent to find series of rocks intermediate between jotunites and mangerites (Lomland dyke -Duchesne and Roelandts, 1983) or quartz-mangerites (Håland dyke -Duchesne, unpublished; Telness dyke - Krause and Pedall, 1980). It should be mentioned that a relation between jotunite and quartz-mangerite by immiscibility of two liquids is hard to confirm. Detailed chemical data indicate that jotunitic liquids can frequently enter the immiscibility field of Roedder (1979), Wiebe (1979) and Philpotts (1981) but remain homogeneous. Globules of jotunitic rocks are frequently found enclosed in acidic material (Wiebe, 1980b; Duchesne et al., 1984a). From that it has been inferred that two melts coexisted (Wiebe, 1984) but these do not necessary result from the unmixing of a single liquid. They indeed frequently show evidence of difference in temperature (chilled contacts between the globules and the host rock; different liquidus minerals in both rocks). If immiscibility really takes place, it appears that it requires very specific conditions of chemical compositions and oxygen fugacity, which are seldom met in the anorthositic environment.

Crystallization of a noritic cumulate can explain quantitatively in a straightforward manner the evolution towards acidic rocks (Duchesne and Roelandts, 1983; Duchesne et al., 1984b). In differentiation diagrams jotunites correspond to the beginning of well defined liquid lines of descent, extending to quartz-mangerites and further to granitic products. Since the noritic cumulate can in turn be split by gravity controlled mechanisms into anorthosite, leuconorite and mafic-rich rocks, it follows that jotunite can give rise to the whole anorthosite suite. The amount of anorthosite produced by the differentiation is however not important, and certainly not sufficient to account for the relatively large volumes of anorthosites found in massifs such as Egersund-Ogna or Åna-Sira. Examples of series of differentiates from jotunitic magmas can be found in the Hidra leuconoritic body and in the Bjerkrem-Sogndal lopolith, allowing for some contamination in the acidic rocks, as already discussed.

The jotunite series presents a Peacock index at the limit between alkalic and alkali-calcic series $\left(50-51 \% \mathrm{SiO}_{2}\right.$ for $\mathrm{CaO}=\mathrm{Na}_{2} \mathrm{O}+\mathrm{K}_{2} \mathrm{O}$ ). It is thus distinct from a tholeiitic series - which is sub alkaline (Irvine and Baragar, 1971)-, though having a high $\mathrm{Fe} / \mathrm{Mg}$ ratio, typically normative orthopyroxene and associated quartz-bearing derivatives. The fractionation trends are characterized by alkali-enrichment at virtually constant Fe/Mg ratios (Bowen trend). Some variation in the latter ratio can occur between different dykes or intrusions. Fenner trends (variation of $\mathrm{Fe} / \mathrm{Mg}$ with constant alkalis) have not been found within the same body (Duchesne and Roelandts, 1983; Duchesne et al., 1984b).

Belonging to the same dyke system in the Egersund-Ogna massif (Rogaland) the Vettaland dyke must be mentioned for its unusual geochemical character (Duchesne et al., 1984b). It is made up of a quartz-ferrodiorite, similar to jotunitic rocks in major elements, except for a high $\mathrm{Fe} / \mathrm{Mg}$ ratio and low $\mathrm{K}_{2} \mathrm{O}$ content. It is thus sub alkaline and belongs to a tholeiitic series. The striking feature is that it is virtually constant in major element geochemistry over a length of about $20 \mathrm{~km}$, but is highly contrasted in trace elements: the north part presents a trace element distribution (including the rare-earth elements) similar to other jotunitic rocks $(\mathrm{La} / \mathrm{Yb}=12 ;$ light rare-earth elements ca.150 times the chondrites, no Eu anomaly); the south part is strongly depleted in large ion lithophile elements and has a bell-shaped rare-earth distribution with a positive Eu anomaly. The Sr initial ratio is identical in both parts. These features point to eutectic partial melting, presumably in dry conditions, of an apatite-bearing gabbroic or noritic cumulate: the model implies a low degree of melting in the south part and a higher degree $(40 \%)$ of the same source rock in the north part (Duchesne et al., 1984b). 


\subsection{Anorthositic and noritic rocks}

Duchesne and Demaiffe (1978) have concluded from trace element evidence that a unique magma cannot account for the whole anorthositic suite. The amplitude of trace element variations in plagioclase indeed covers several orders of magnitude, which implies extreme fractionation and would lead to unrealistically small amounts of residual liquids compared to what is observed for intermediate and acidic rocks. While a jotunitic magma can account for intermediate to acidic liquids, a more basic magma is a good candidate for the anorthosite-norite members of the suite.

Labrador and Grenville anorthosites are associated with a series of rocks grading into noritic and/or troctolitic rocks through enrichment in mafics. Troctolitic rocks (i.e. olivine gabbro) are conspicuous in Labrador, Lofoten (N.Norway), etc... but have only been found in small amount in many Grenville anorthosites, e.g. Rogaland, Morin, etc.. (see De Waard et al., 1974).

Recent data (see Morse, 1982) on the anorthite content of the plagioclase in Labrador massifs show a continuous variation from $\mathrm{An}_{90}$ to $\mathrm{An}_{30}$ with a median value between $\mathrm{An}_{40}$ and $\mathrm{An}_{50}$. According to Morse it is no longer justified to distinguish a labradorite-type from an andesine-type anorthosite (Isachsen, 1969). Nevertheless labradorite plagioclases $\left(\mathrm{An}_{50-70}\right)$ are exceptional in Grenville type anorthosites. The only occurrence in Rogaland is in the Egersund-Ogna massif where they occur in the foliated inner margin of the massif (see above) and are occasionally associated with olivine (troctolite). In Grenville type anorthosites, the composition of the plagioclase is generally monotonous at large (e.g. in Rogaland 120 determinations of the An content of the plagioclase gives an average of $44.6 \mathrm{wt} \%$ An with $\mathrm{s}=3.2 \%$ - Zeino-Mahmalat in Duchesne and Demaiffe, 1978 - and in the central anorthosite of the Egersund-Ogna massif, An $=43.0 \pm 2.0$ for 18 plagioclases). Some megacrysts of plagioclase, especially those associated with giant pyroxenes (see below) are somewhat more calcic $\left(\mathrm{An}_{55}\right.$-Duchesne and Maquil, 1984).

\subsection{Megacrysts of Al-rich orthopyroxenes}

Whatever the composition of the plagioclase and the nature of the mafics, a unifying character of massif-type anorthosite is the occurrence of megacrysts of aluminous bronzitic pyroxenes $\left(7-9 \% \mathrm{Al}_{2} \mathrm{O}_{3}\right)$, showing exsolutions of plagioclase and occasionally of green spinel (Emslie, 1975a). They occur as phenocrysts or in subophitic agglomerates with giant plagioclases $\left(^{2}\right)$. The pressure-temperature conditions of crystallization of the giant crystals are crucial for understanding the anorthosites. Very little experimental data are however available. Reconnaissance works by Emslie (1975b) and Maquil (1978) suggest a pressure control, the latter having shown that congruent melting only takes place in a pressure window around 10-15 kbars. Accordingly the giant pyroxenes and associated plagioclases would have crystallized in deep-seated conditions (40-60 km), at a lower level than that at which they were eventually emplaced. Morse $(1975,1982)$ on the other hand favours rapid crystallization, in place, from plagioclase-rich magmas, a process which appears to the present author difficult to reconcile with the extreme size of the megacrysts.

\subsection{Liquid magmas}

In Labrador chilled margins, marginal rocks or fine-grained dyke rocks have various compositions: high-Al and low-Al gabbros (Emslie, 1978), high Al-norite or troctolite (Morse, 1982), leuconorite (gabbroic anorthosite) sometimes with colour index as low as $10-15 \%$ (Wiebe, 1980a). This indicates the existence of magmas, not necessarily completely liquid but already loaded with crystals, and also not necessarily parental to the series.

The generation of such liquids is explained by a variety of mechanisms, all of them implying a deep seated stage of crystallization. It is indeed convenient when starting from a basaltic composition to fractionate mafic minerals in a lower crustal magma chamber. Experimental data at high pressure in simple binary and ternary systems (Presnall et al., 1978) have confirmed earlier work (Lindsley and Emslie, 1968) and shown a reduction of the field of stability of plagioclase relative to the mafics with increasing pressure, thus permitting the production at high pressure of plagioclase-enriched liquids by protracted crystallization and subtraction of mafic minerals. Such hyperfeldspathic liquids (high-Al gabbro or norite, leuconorite) might then rise rapidly through the crust and reach a shallower magma chamber where they could crystallize to produce a large amount of plagioclase, before crystallizing along a cotectic where mafics reappear. In the second magma chamber gravity-controlled fractional crystallization also contributes to the formation of anorthosites, leuconorites and norites by cumulate processes. Residual liquids are represented by small intrusions and dykes of Fe-Ti oxides-bearing norites. Giant Al-pyroxenes have crystallized in the first stage (Emslie, Wiebe) and are carried in the melt to the second chamber as phenocrysts or glomeroporphyric aggregates with plagioclases. An alternative explanation (Morse) is 
that they simply result from rapid metastable crystallization in the shallower second stage.

It has been suggested that since the barrier of nucleation of plagioclase is higher than those of the mafics, the cotectic crystallization of plagioclase could be delayed, thus leading to a metastable enrichment of the liquid in plagioclase component (Morse, 1982). This hypothesis is difficult to test but current petrographic observation indicates that poecilitic interstitial structures are commonly developed by pyroxene (subophitic texture) and not by plagioclase. This tends to show that pyroxene nucleates less easily than plagioclase.

\subsection{Crystal mush and diapirism}

The Labarador model in which liquid magmas play an important role cannot be used without some alteration to account for the Grenville anorthosites. Major differences concern the degree of crystallization of the magma and the mechanism of intrusion.

A conspicuous petrographic feature of the Grenville anorthosite is their protoclastic structure, already noted by Bowen $(1928, p .171)$, that is the granulation of early formed minerals, such as plagioclase, before entire consolidation of the rock. The deformation obviously can only be produced when crystals are mutually in contact, which implies a high degree of consolidation, that is a crystal mush. A deformed crystal mush can hardly preserve the original composition of the magma because of the more or less inevitable squeezing out of the residual liquids. The classical concept of filter-press indeed finds numerous illustrations in the field and under the microscope in Grenville anorthosites, e.g. in Morin (Martignole and Schrijver, 1970), in Rogaland (J. Michot, 1960), etc. Thus evidence of in situ crystallization from liquids is restricted to late stage phenomena. No chilled margin to large massifs has been recognized. Anorthositic dykes are not rare and can readily be interpreted as injections of a crystal mush.

The conformable contacts of the massifs with the foliation in the metamorphic envelope, the frequency of dome structures and in some cases the parallelism of the foliation in the border of the intrusion with flow structures in inner parts of the intrusion, indicating a mechanical friction engendered by the upward flowing central mass, strongly suggest an emplacement of the crystal mush by a gravity controlled process.

Perhaps the best example of an anorthositic mantled dome is the Egersund-Ogna massif in Rogaland with a well preserved gneissic border of virtually constant thickness. Other Rogaland massifs - Ana-Sira and AmdalHelleren-Rödland - have steeper contacts and no gneissic margins. They can nevertheless be considered as variants of the Egersund-Ogna massif, which have broken through and disrupted an early formed gneissic border, fragments of which are found as blocky inclusions or in the neighbouring Håland massif.

In Rogaland, evidence of a crystallization episode at high pressure is provided, as in Labarador massifs, by the occurrence of giant Al-orthopyroxenes. Trace elements in these minerals (Maquil et al., 1980; Duchesne and Maquil, 1984) show variable but high Cr contents $(600-1500 \mathrm{ppm})$, which strongly suggest that they started to crystallize in equilibrium with a liquid not depleted by the crystallization of mafic minerals. Small variations of the other transition elements compared to $\mathrm{Cr}$ are also observed. The averages and standard deviations on a hundred samples from Egersund-Ogna are the following $\mathrm{V}=281 \pm 29 \mathrm{ppm}, \mathrm{Zn}=133 \pm 22 \mathrm{ppm}, \mathrm{Co}=103 \pm 7$ $\mathrm{ppm}, \mathrm{Ni}=276 \pm 45 \mathrm{ppm}, \mathrm{MnO}=0.24 \pm 0.02 \%$. This indicates that in the interval of liquidus crystallization of the giant orthopyroxenes, there is no variation of the various elements (except $\mathrm{Cr}$ ) in the successive liquids. In other words, the bulk partition coefficients of the various elements (except $\mathrm{Cr}$ ) between the minerals and the melt have remained close to unity. Since disappearance of minerals or appearance of new minerals in the course of fractionation drastically modify the bulk partition coefficient of some elements, e.g. olivine for $\mathrm{Ni}, \mathrm{Fe}$-Ti oxides for $\mathrm{V}$, the constancy observed here precludes coprecipitation of Al-pyroxene with the latter minerals. Absence of olivine is also consistent with high pressures since it has been shown that the association of forsterite with plagioclase becomes unstable as pressure increases (Kushiro and Yoder, 1966, Presnall et al., 1978). In the first stage of crystallization, a plagioclase $\left(\mathrm{An}_{55}\right)$ also precipitates alone or with the Al-orthopyroxene (Maquil et al., 1980; Duchesne and Maquil, 1984). The relatively low An content for a plagioclase in equilibrium with a $\mathrm{Cr}$ rich melt - i.e. a basic liquid - also suggests a crystallization at high pressure according to the experiments of T.H. Green (1969). These geochemical data are not sufficient to assess with accuracy the composition of the parental magma of the deep-seated stage, but an overall basaltic composition, as in Labrador, is very likely.

Egersund-Ogna also provides indications of crystallization of the gneissic border at lower pressure than the central part. There, giant Al-pyroxenes are commonly found, deformed and stretched to various degrees along the foliation plane. Undeformed megacrysts are poorer in $\mathrm{Al}$ than in the central part (3.5-6\% $\mathrm{Al}_{2} \mathrm{O}_{3}$ versus 7-9\%) with broadly the same $\mathrm{Fe} / \mathrm{Mg}$ ratio. Moreover the An content of the plagioclase from border rocks can reach 
values as high as $\mathrm{An}_{70}$ with a low Sr content (Duchesne, 1968; Duchesne and Demaiffe, 1978; Maquil et al., 1980) and olivine $\left(\mathrm{Fo}_{70} \mathrm{Fa}_{30}\right)$ is not rare as a principal mafic mineral (troctolite) (Duchesne and Maquil, 1984). All these compositions point to lower pressure of crystallization than in the central part of the massif.

Final emplacement of the massif took place in still lower pressure conditions. The norites which enclose the agglomerates of plagioclase and orthopyroxene megacrysts are made up of an orthopyroxene without lamellae of plagioclase and thus relatively poor in Al. Moreover the Al contents of the pyroxenes of the late stage noritic liquids are also very low (1-2 \% $\mathrm{Al}_{2} \mathrm{O}_{3}$ in orthopyroxene) (Maquil and Duchesne, 1984). The temperature of the massif remained high during the emplacement. Maquil and Duchesne (1984) record in megapyroxenes exsolution temperatures of $1060^{\circ} \mathrm{C}$ and recrystallization temperatures in the gneissic border as high as $990^{\circ} \mathrm{C}$, according to the Wells (1977) geothermometer. Moreover according to a recent review by Maijer et al. (1984) the igneous masses have developed in the metamorphic envelope a large aureole of static granulite facies metamorphism (M2 phase) in which osumilite appears (Maijer et al., 1977) up to more than $10 \mathrm{~km}$ from the contact.

In conclusion the earlier stage of crystallization and the nature of the parental magma can be similar in Grenville type and in Labrador anorthosites but the mechanisms of emplacement are different: in Labrador a liquid magma rises to a magma chamber where it crystallizes while in the Grenville type a hot crystal mush forces its way to shallower levels in the crust.

The reasons of such a difference in behaviour are not yet understood. Both processes can take place in anorogenic conditions though in many Grenville cases the emplacement shortly predates or is penecontemporaneous with the last pervasive regional event (Schrijver, 1975; Baer, 1981). Future work should pay some attention to testing the old hypothesis of "leuconoritic anatexis" (P. Michot, 1955) or "basic palingenesis" of J. Michot (1960) in the Grenville type. Theoretically small amounts of partial melting can indeed be produced, during the diapiric uprise. As already said before, experiments in the plagioclase-mafics systems show that a drop in pressure shifts the cotectic lines towards the mafic pole of the systems and lowers the liquidus temperatures. It is thus conceivable that a decrease in pressure combined with a small decrease in temperature (adiabatic gradient?) would cause the melting of a solid leuconorite. This would be an elegant way to "reactivate" older massifs.

\section{CONCLUSIONS}

Contrary to Labrador anorthosites, which were emplaced atectonically and were not subsequently deformed, Grenville type anorthosites are deformed. The deformation is however not entirely due to a regional tectonic event but can be caused, in part or totally, by the emplacement process itself (syn-emplacement deformation). Conspicuous evidence is provided by the Egersund-Ogna mantled dome (Rogaland). Paradoxically pre- or earlyGrenvillian isotopic ages are recorded in Grenville anorthosites, which implies either extremely long cooling times or reactivation by partial melting of an older solid anorthosite massif.

Acidic rocks associated with anorthosites can be produced by crustal anatexis but can also derive directly from the fractional crystallization of jotunitic magmas, coeval with massive anorthosites but not residual to them. Contamination of acidic differentiates with anatectic melts is common. The jotunitic magma can also produce andesine anorthosite cumulates, but in minor quantities relative to noritic cumulates. The jotunite series of rocks are alkaline to alkali-calcic, with high, virtually constant $\mathrm{Fe} / \mathrm{Mg}$ ratios. They show variable $\mathrm{Sr}$ isotopic initial ratios $(0.7050$ - 0.7085), precluding direct derivation from mantelic sources.

The parental magma of massif-type anorthosites is difficult to characterize with accuracy, particularly in Grenville type where chilled margins are absent. The composition of early-formed minerals (major and trace elements) does not however contradict a basaltic nature. Three types of magmas (basaltic, jotunitic and acidic) can thus account for the anorthosite suite, each magma generating part of the suite, with some overlapping of the different parts.

In Rogaland, as probably in Labrador, a starting stage of crystallization at great depth is indicated by the occurrence of megacrysts of Al-orthopyroxenes, now containing exsolutions of plagioclase lamellae. After this first stage, differences in the evolution appear between the Labrador and Grenville types. In Labrador a liquid magma rapidly rises in the crust up to a magma chamber where it fractionates. In Rogaland, as well as in all deformed Grenville anorthosites, a high temperature crystal mush, in which large aggregates of giant plagioclases and Al-orthopyroxenes formed at depth are preserved, diapirically rises, reaches shallower levels in the crust and crystallizes progressively as the pressure lowered. Internal friction due to the movement of the 
mass produces a deformation of the envelope near the contact and of the inner border of the pluton as well as a general protoclasis of the plagioclase.

The anorthosite suite appears complex since several types of magmas are involved. The broadly basaltic nature inferred for the parental magma of the anorthosite-norite series seems to preclude any relation to andesitic magmatism and thus to an Andean-type subduction mechanism. Uncertainty about the exact nature in the basalt family prevents any further reconstruction of the geodynamic environment in terms of actual plate tectonic concepts. There is however a general consensus on the atectonic character of the Labarador anorthosites and strong evidence that Grenville-type anorthosites can also be emplaced atectonically, though they usually precede a regional pervasive deformation.

The geodynamic significance of the jotunitic magmatism remains to be assessed. It is tempting to interpret the close temporal and spatial relation with massif anorthosites and the strong isotopic crustal signature as indicating partial fusion of the lower crust by the rising anorthosite diapirs. Geochemical inversion methods appear promising to give a better knowledge of the source region, anorthosite acting thus as probe of the lower crust.

\section{ACKNOWLEDGMENTS.}

The author wishes to express his gratitude to D. Demaiffe and R. Maquil for continued cooperation on the Rogaland studies and to J. Martignole for highly stimulating discussions. He also thanks G. Pouliot and R.A. Wiebe for discussions in the field and his students A. Boutefeu, J.M. Piron, B. Denoiseux and E. Wilmart, who helped in the Rogaland work. The paper has greatly benefited from the reviews of J. Martignole and R.F. Emslie. This work was supported by the Belgian F.N.R.S.

\section{NOTES.}

(1) in the latest review paper of Morse (1982), 25\% of the papers cited in the bibliography and directly concerned with anorthosites belong to this category. The present review will increase the proportion up to $28 \%$.

(2) Martignole (pers. comm.) has drawn my attention to the fact that the opx (hypersthene) from pegmatitic norites or masses with sharp contacts can also be rich in $\mathrm{Al}$, and therefore must be generated by a different process from that of the giant bronzites from the anorthosite. Maquil and I have observed that (1) the Al content is always lower $\left(4-6 \% \mathrm{Al}_{2} \mathrm{O}_{3}\right)$ than in the giant bronzites; (2) they are frequently deformed (kinks, granulation); (3) in many cases they are enclosed in a fine-grained norite containing opx of lower Al-content (Maquil and Duchesne, 1984). In our model, they started crystallizing at still high pressures but at lower values than the bronzites and were carried to the final level of emplacement as a crystal mush lubricated by the interstitial norite.

\section{REFERENCES}

ASHWAL L.D. (1982) Mineralogy of mafic and Fe-Ti oxide-rich differentiates of the Marcy anorthosite massif, Adirondacks, New-York. Amer.Miner. 67, 14-27.

ASHWAL L.D. and SEIFERT K.E. (1980) Rare-earth element geochemistry of anorthosite and related rocks from the Adirondacks, NewYork, and other massif complexes. Geol. Soc. Amer. Bull. Part II, 91, 659-684.

ASHWAL L.D., WOODEN J.L. and SHIH C.Y. (1980) Nd and Sr isotope geochronology of the Marcy anorthosite massif, Adirondacks, New-York (Abstract). Geol. Soc. Amer. Meeting, Abstracts with program 12, 380.

BAER A.J. (1981) A Grenvillian model of Proterozoic plate tectonics. In "Precambrian Plate tectonics" (KRONER A., ed.), Elsevier, 353385 .

BARRAUD C. and MARTIGNOLE J. (1984) Diapirism of the Morin Anorthosite: evidence from the petrofabric of quartz c-axes of surrounding granulites (Abstract). J. Struct. Geol. (in press).

BLACK R. (1965) Sur la signification pétrogénétique de la découverte d'anorthosites associées aux complexes sub-volcaniques du Niger. C.R. Acad. Se. Paris, D260, 5829-5832. 
Published in: Feldspars and Felspathoids (1984) W.S. Brown (ed) NATO ASI, pp. 411-433.

Status: Postprint (Author's Version)

BOWEN N.L. (1928) The evolution of the igneous rocks. Princeton University Press, 332p.

BUDDINGTON A.F. (1972) Differentiation trends and parental magmas for anorthositic and quartz mangerite series, Adirondacks, NewYork. Geol. Soc. America Mem. 132, 477-488.

CARUBA R., DUCHESNE J.C. and IACONNI P. (1984) Zircon from Rogaland charnockitic rocks (S.W. Norway): Petrogenetic implications. Submitted.

CHOU C.L. and EMSLIE R.F. (1979) Rare earth element abundances in the Harp Lake Complex, Labrador (Abstract). GAC and MAC joint meeting in Montreal.

DEMAIFFE D., DUCHESNE J.C, MICHOT J. and PASTEELS P. (1973) Le massif anorthosito-leuconoritique d'Hidra et son faciès de bordure. C.R. Acad. Sci. Paris 277, sér.D, 17-20.

DEMAIFFE D., DUCHESNE J.C. and HERTOGEN J. (1979) Trace element variations and isotopic composition of charnockitic acidic rocks related to anorthosites (Rogaland - S.W.Norway). In "Origin and distribution of the elements" (AHRENS L.H., ed.), Pergamon Press, 417-429.

DEMAIFFE D. and HERTOGEN J. (1981) Rare earth geochemistry and strontium isotopic composition of a massif-type anorthositiccharnockitic body : the Hidra massif (Rogaland, S.W. Norway). Geochim. Cosmochim. Acta 45, 1545-1561.

DE WAARD D., DUCHESNE J.C. and MICHOT J. (1974) Anorthosites and their environment. In : "Géologie des domaines cristallins" (BELLIERE J. and DUCHESNE J.C, eds) Centenaire Soc. Géol. Belgique, Liège, 323-346.

DEWEY J.F. and BURKE K.C.A. (1973) Tibetan, Variscan and Precambrian basement reactivation : products of continental collision. J. Geol. 81, 683-692.

DUCHESNE J.C. (1968) Les relations Sr-Ca et Ba-K dans les plagioclases des anorthosites du Rogaland méridional. Ann. Soc. Géol. Belgique 90, 643-656.

DUCHESNE J.C. (1978) Quantitative modeling of Sr, Ca, Rb, and K in the Bjerkrem-Sogndal layered lopolith (S.W. Norway). Contr. Mineral. Petrol. 66, 175-184.

DUCHESNE J.C, ROELANDTS I., DEMAIFFE D., HERTOGEN J., GIJBELS R. and DE WINTER J. (1974) Rare-earth data on monzonoritic rocks related to anorthosites and their bearing on the nature of the parental magma of the anorthositic suite. Earth Planet. Sci. Lett. 24, 325-335.

DUCHESNE J.C. and DEMAIFFE D. (1978) Trace elements and anorthosite genesis. Earth Planet. Sci. Lett. 38, $249-272$.

DUCHESNE J.C. and MAQUIL R. (1981) Evidence of syn-intrusive deformation in South-Norwegian Anorthosites (Abstract). Terra cognita, Spec.issue, 94

DUCHESNE J.C. and MAQUIL R, (1984) The Egersund-Ogna body. In : "The Precambrian of South Norway" (MAIJER C et al. eds), submitted to Norsk. Geol. Unders.

DUCHESNE J.C. and ROELANDTS I. (1983) Ferrodiorites in massif-type anorthosites : residual liquids or partial melts from the lower crust? (Abstract). Terra cognita 3, 142

DUCHESNE J.C, DEMAIFFE D. and WILMART E. (1984a) The contact zone of the Ana-Sira anorthosite : the monzonoritic intrusion of Fidsel, the granulitic supracrustal series of Trolldalen, the Hidra body and the charnockitic farsundites. In : "The Precambrian of South Norway" (MAIJER C. et al. eds), submitted to Norsk Geol. Unders.

DUCHESNE J.C, ROELANDTS I., DEMAIFFE D. and WEIS D. (1984b) Petrology and geochemistry, including REE, Sr and Pb isotopic compositions, of monzonoritic dykes in the Egersund anorthosite province, submitted to Contr. Mineral. Petrol.

EMSLIE R.F. (1973) Some chemical characteristics of anorthosite suites and their significance. Can. J. Earth Sci. 10, 54-71.

EMSLIE R.F. (1975a) Pyroxene megacrysts from anorthositic rocks : new clues to the source and evolution of the parent magmas. Can. Miner. 13, 138-145.

EMSLIE R.F. (1975b) High pressure pyroxene megacrysts from anorthositic rocks and their bearing on the genesis of the parent magma (Abstract). Geol. Soc. Am. Meeting, Abstracts with program, 752-753.

EMSLIE R.F. (1978) Anorthosite massifs, Rapakivi granites, and Late Proterozoic rifting of North America. Precambr. Res. 7, 61-98.

EMSLIE R.F. (1980) Geology and petrology of the Harp Lake Complex, Central Labrador : an example of Elsonian magmatism. Geol. Surv. Canada Bull. 293, 136 p.

FALKUM T. and PETERSEN J.S. (1980) The Sveconorwegian orogenic belt, a case of Late Proterozoic plate-collision. Geol. Rund. 69, 
622-647.

GREEN T.H. (1969) Experimental fractional crystallization of quartz diorite and its application to the problem of anorthosite origin. In "Origin of anorthosite and related rocks" (ISACHSEN Y.W., ed.), N.Y. State Mus. Sci. Serv. Mem. 18, 25-33.

HERMANS G.A.E.M., TOBI A.C., POORTER R.P.E. and MAIJER C. (1975) The high-grade metamorphic Precambrian of the SirdalOrsdal area, Rogaland/Vest-Agder, S.W. Norway. Nor. Geol. Unders. 318, 51-74.

IRVINE T.N. and BARAGAR W.R.A. (1971) A guide to the chemical classification of the common volcanic rocks. Can. J. Earth Sci. 8 , 523-548.

ISACHSEN Y.W. (Ed.) (1969) Origin of anorthosite and related rocks. N.Y. State Mus. Sci. Serv. Mem 18, 466 p.

KRAUSE H. and PEDALL G. (1980) Fe-Ti mineralizations in the Ana-Sira anorthosite, Southern Norway. In "Metallogeny of the Baltic Shield" (JOAKO-SIIVOLA, ed.), Geol. Surv. of Finland 307, 56-83.

KUSHIRO I. and YODER H.S. (1966) Anorthite-forsterite and anorthite-enstatite reactions and their bearing on the basalt-eclogite transformation. J. Petrol. 7, 337-362.

LINDSLEY D.H. and EMSLIE R.F. (1968) Effect of pressure on the boundary curve in the system diopside-albite-anorthite. Carnegie Inst. Washington Yb.66, 479-480.

MAIJER C., JANSEN J.B.H., WEVERS J. and POORTER R.P.E. (1977) Osumilite, a mineral new to Norway. Norsk Geol. Tidsskr. 57, 187-188.

MAIJER C., DUCHESNE J.C., FALKUM T., SIGMOND E., TOBI A.C. and TOURET J. (eds) (1984) "The Precambrian of Southern Norway", submitted to Norsk Geol. Unders.

MAQUIL R. (1978) Preliminary investigation on giant orthopyroxenes with plagioclase exsolution lamellae from the Egersund-Ogna anorthositic massif (S.W. Norway) NERC Publ. Série D - 4th report 1975-1978, 144-146.

MAQUIL R. (1980) Field relations of the Egersund-Ogna anorthosite (Abstract). Colloqium high-grade metamorphic Precambrian and its intrusive masses, Utrecht, 8-9 mai.

MAQUIL R., ROELANDTS I., HERTOGEN, J. and DUCHESNE J.C. (1980) Orthopyroxènes géants et plagioclases associés dans l'anorthosite d'Egersund-Ogna (S.W. Norvège). 8ème Réunion Ann. Sci. de la Terre, Marseille, Soc. Geol. France, 238.

MAQUIL R. and DUCHESNE J.C. (1984) Two-pyroxene geothermometry and the emplacement of the Egersund-Ogna massif (Rogaland, S.Norway). Ann. Soc. Géol. Belgique (in press).

MARTIGNOLE J. and SCHRIJVER K. (1970) Tectonic setting and evolution of the Morin anorthosite, Grenville Province, Quebec. Bull. Geol. Soc. Finland 42, 165-209.

MARTIGNOLE J. and SCHRIJVER K. (1972) Petrology and structure of the Morin anorthosite. 24th Int. Geol. Congr. Montreal, Guidebook of exc. B-01.

MICHOT J. (1960) La palingenèse basique. Acad. Roy. Belgique, Bull cl. sc. 5, 46, 257-268.

MICHOT P. (1955) L'anatexie leuconoritique. Acad. Roy. Belgique, Bull cl. sc. 5, 41,374-385.

MICHOT P. (1960) La géologie de la catazone : le problème des anorthosites, la palingenèse basique et la tectonique catazonale dans le Rogaland méridional (Norvège méridionale). Norges Geol. Unders. 212g, 1-54.

MICHOT P. (1965) Le magma plagioclasique. Geol. Rundschau, 54, 956-976.

MOREAU B. (1981) Evolution du massif anorthositique de Vaskojoki, Finlande du Nord. Ann. Soc. Géol. Belgique, 104, $261-267$.

MOREAU C. (1982) Les complexes annulaires anorogéniques à suites anorthositiques de l'Air central et septentrional (Niger). Doctorat thesis. University of Nancy, $356 \mathrm{p}$.

MORSE S.A. (1975) Plagioclase lamellae in hypersthene, Tikkoatokhakh Bay, Labrador. Earth Planet. Sci. Lett. 26, $331-336$.

MORSE S.A. (1982) A partisan review of Proterozoic anorthosites. Amer. Miner. 67, 1087-1100.

PETERSEN J.S. (1980a) The zoned Kleivan-granite - an end member of the anorthosite suite in Southwest Norway. Lithos 13, 79-95.

PETERSEN J.S. (1980b) Rare earth element fractionation and petrogenetic modelling in charnockitic rocks, Southwest Norway. Contrib. Mineral. Petrol. 73, 161-172. 
Published in: Feldspars and Felspathoids (1984) W.S. Brown (ed) NATO ASI, pp. 411-433.

Status: Postprint (Author's Version)

PHILPOTTS A.R. (1966) Origin of the Anorthosite-Mangerite rocks in Southern Quebec. J. Petrol. 7, 1-64.

PHILPOTTS A.R. (1981) A model for the generation of massif-type anorthosites. Can. Miner., 19, 233-253.

PRESNALL D.C., DIXON S.A., DIXON J.R., O'DONNEL T.H., BRENNER N.L., SCHROCK R.L. and DYCUS D.W. (1978) Liquidus phase relations on the join diopside-forsterite-anorthite from $1 \mathrm{~atm}$ to $20 \mathrm{kbar}$ : their bearing on the generation and crystallization of basaltic magmas. Contr. Mineral. Petrol. 66, 203-220.

ROEDDER E. (1979) Silicate liquid immiscibility in magmas. In "The evolution of the igneous rocks : Fiftieth Anniversary Perspectives" (YODER H.S., éd.), Princeton University Press, 15-57.

ROELANDTS I. and DUCHESNE J.C. (1979) Rare-earth elements in apatite from layered norites and iron-titanium oxide ore-bodies related to anorthosites (Rogaland, S.W. Norway). In "Origin and distribution of the elements" (AHRENS L.H., ed.) Pergamon, 199-212.

SCHRUVER K. (1975) Deformed rock of a composite diapir in granulite facies. Geotekt. Forsch, 49, 1-118.

SMITH J.V. (1982) Heterogeneous growth of meteorites and planets, especially the Earth and Moon. J.Geol. 90, 1-48.

TAYLOR S.R. (1975) Lunar Science : a post-Apollo View. Pergamon, 372 p.

WATSON E.B. (1979) Apatite saturation in basic to intermediate magmas. Geophys. Res. Lett. 6, 939-940.

WEAVER B.L., TARNEY J., WINDLEY B.F. and LEAKE B.I. (1982) Geochemistry and petrogenesis of Archean metavolcanic amphibolites from Fiskenaesset, S.W. Greenland. Geochim. Cosmochim. Acta 46, 2203-2215.

WEIS D. and DEMAIFFE D. (1983) Pb isotope geochemistry of a massif-type anorthositic-charnockitic body : the Hidra massif (Rogaland, S.W. Norway). Geochim. Cosmochim. Acta (in press).

WEIS D. and DUCHESNE J.C (1983) Pb isotopic compositions in the Egersund-Ogna anorthosite (S.W. Norway); an indication of a Gothian magmatic event? (Abstract). Terra cognita 3, 140.

WENDLANDT R.F. (1981) Influence of C02 on melting of model granulite facies assemblage : a model for the genesis of charnockites. Amer. Miner. 66, 1164-1174.

WELLS P. (1977) Pyroxene thermometry in simple and complex systems. Contrib. Mineral. Petrol. 62, 129-139.

WIEBE R.A. (1979) Fractionation and liquid immiscibility in an anorthositic pluton of the Nain Complex, Labrador. J. Petrol. $20,239-269$.

WIEBE R.A. (1980a) Anorthositic magmas and the origin of Proterozoic anorthosite massifs. Nature 286, $564-567$.

WIEBE R.A. (1980b) Commingling of contrasted magmas in the plutonic environment : examples from the Nain anorthositic Complex. J. Geol. 88, 197-209.

WIEBE R.A. (1984) Fractionation and magma mixing in the Bjerkrem-Sogndal lopolith (S.W. Norway) : evidence for the composition of residual liquids. Submitted to Lithos.

WIELENS J.B.W., ANDRIESSEN P.A.M., BOELRIJK N.A.I.M., HEBEDA E.H., PRIEM, H.N.A., VERDURMEN E.A.T. and VERSCHURE R.H. (1981) Isotope geochronology in the high-grade metamorphic Precambrian of Southwestern Norway : new data and reinterpretations. Norges Geol. Unders. 359, 1-30.

WINDLEY B.F. (1977) The evolving continents. John Wiley, 385p.

WINDLEY B.F., BISHOP F.C. and SMITH J.V. (1981) Metamorphosed layered igneous complexes in Archean granulite-gneiss belts. Ann. Rev. Earth. Planet. Sci. 9, 175-198.

WOUSSEN G., DIMROTH E., CORRIVEAU L. and ARCHER P. (1981) Crystallization and emplacement of the Lac St Jean anorthosite Massif (Quebec, Canada). Contrib. Mineral. Petrol. 76, 343-350. 